\title{
LEITURAS MAIS AFAMADAS DO QUE DITOSAS: OS LUSIADAS SOB A PENA DE VOLTAIRE E SEUS CONTRAPONTOS EM LA LUSIADE
}

\section{Rafael Souza Barbosa}

RESUMO: A primeira tradução de Os Lusíadas na França, realizada por Duperron de Castera (1735), opôs-se diretamente, por meio de seus prefácio e notas, ao Ensaio sobre o poema épico (1727), escrito por Voltaire. Ela não só permitiu a inserção da épica camoniana no campo literário francês, mas também posicionou-se em relação a leituras do poema feitas até então. São nas páginas impressas de La Lusiade que Castera subverte a crítica de Voltaire. Assim, Camões atravessou o século XVIII em meio a um fogo cruzado de disputas literárias, cuja mediação será decisiva na sua intensa recepção durante o século XIX.

PALAVRAS-CHAVE: leitura, história da literatura, Camões, recepção literária, estudos de tradução.

RESUMÉ : La première traduction de Os Lusíadas en France, réalisée par Duperron de Castera (1735), a été opposée directement, par son préface et ses notes, à l'Essai sur le poème épique (1727), écrit par Voltaire. Elle a permis tant la rentrée de l'épique camonienne dans le champ littéraire français, que la mise en oeuvre des lectures du poème faites jusqu'alors. C'est dans les pages de La Lusiade que Castera a renversé la critique voltairienne. Ainsi, parmi un enjeu des disputes littéraires, Camões rentre le XIXe siècle, attirant l'attention de nombreux lecteurs en France.

MOTS-CLÉS : lecture, histoire de la littérature, Camões, réception littéraire, études de traduction.
1 Graduando em letras e bolsista de iniciação científica (BIC/ PROPESQ) da UFRGS. Email: rafaelsouzabarbosa@gmail.com 
Este receberá, plácido e brando,

No seu regaço os Cantos que molhados

Vêm do naufrágio triste e miserando,

Dos procelosos baxos escapados,

Das fomes, dos perigos grandes, quando

Será o injusto mando executado

Naquele cuja Lira sonorosa

Será mais afamada que ditosa.

Os Lusiadas, Canto $X$

\section{Comentário inicial}

Este trabalho decorre de um estudo mais amplo sobre a recepção do legado camoniano ${ }^{2}$ na França na primeira metade do século XIX e faz parte do projeto de pesquisa Ferdinand Denis - bistoriador da literatura, leitor de Camóes ${ }^{3}$, coordenado pela professora Regina Zilberman no Instituto de Letras da Universidade Federal do Rio Grande do Sul (IL/UFRGS). Ele se propõe a abordar a relação estabelecida entre a primeira tradução para o francês de Os Lusíadas (1735), realizada por Duperron de Castera, e o Ensaio sobre o poema épico (1727), escrito por Voltaire, tratando das declaradas discordâncias do primeiro em relação ao segundo. Tal divergência tornouse decisiva para a recepção de Camões no século XIX, pois permitiu certa continuidade na leitura do épico camoniano e garantiu, prospectivamente, a sua divulgação e permanência no campo literário francês.

\section{Os Lusíadas, de Portugal a França}

Os Lusíadas acumulou leituras significativas em Portugal a partir de 1572, com parecer do Frei Bartolomeu Ferreira, impresso na edição princeps, mas foi na Espanha que algumas leituras e menções projetaram o épico português no espaço cultural europeu ${ }^{4}$. Elas se tornaram especialmente abundantes após a publicação de duas traduções concomitantes de Os Lusiadas em 1580, patrocinadas por Felipe II e empreendidas pelas universidades de Salamanca e Alcalá. Segundo Vanda Anastácio (2004, p. 8), essas traduções integraram uma estratégia política de sedução e de intimidação a favor do herdeiro castelhano do trono português que, ao divulgar o épico camoniano, acabou atribuindo ao poema o valor simbólico de representante de uma cultura. Além disso, as duas traduções não foram submetidas à censura eclesiástica, de modo que, enquanto circulava em Portugal uma edição profundamente modificada ${ }^{5}$ do épico, da qual diversos
2 Achamos mais adequado o emprego da expressão legado camoniano em detrimento de obras camonianas, uma vez que tais recepções abarcam tanto obras atribuídas ao poeta quanto outros textos que elas suscitaram, especialmente biografias e comentários exegéticos. Além disso, a centralidade das discussões sobre autoria e do trabalho de fixação de textos no campo dos estudos camonianos impossibilita qualquer referência genérica a um cânone (v. AZEVEDO-FILHO, 1987; AGUIAR E SILVA, 1975).

3 Tal projeto divide-se em dois eixos: o primeiro trata da tradução comentada da obra Résumé de l'bistoire littéraire du Portugal, suivi du Résumé de l'bistoire littéraire du Brésil (1826), escrita por Ferdinand Denis, e do resgate e da atualização dos textos em que o autor baseou a sua pesquisa; o segundo trata da recepção de Luís de Camões nas primeiras décadas do século XIX, em língua portuguesa, haja vista a sua centralidade naquela obra.

4 O impacto decisivo exercido por leituras e apropriações castelhanas durante a União Ibérica colaboraram diretamente com a consagração de Camões como príncipe dos poetas em Portugal, cujo período pode ser estabelecido entre 1572 e 1721 (PIRES, 1982).

5 Frei Bartolomeu Ferreira foi o responsável pela adaptação e redação em português das regras do Index Librorum Probibitorum de 1581. Ele interferiu largamente nas demais edições de Os Lusíadas e foi o autor dos desastrosos comentários que acompanham a edição de 1584 (dos piscos). 
versos e a cena da ilha dos amores foram suprimidos, circulavam na Espanha duas edições minuciosas e integrais do poema. Isso permitiu que ele fosse lido e de algum modo incorporado ao patrimônio cultural espanhol por intermédio de poetas e escritores (HUE, 2009, p. 87), como Miguel de Cervantes e Lope de Vega, cuja admiração por Camões inscrevia-o nas suas obras. Os Lusíadas somente alcançou um contexto europeu mais amplo quando parte do patrimônio cultural espanhol também o fez, atrelando-se decisivamente a ele ao longo, pelo menos, dos séculos XVII e XVIII, e foi reconhecido desde muito cedo por sua ampla divulgação na Espanha e por sua consequente associação simbólica a Portugal (ANASTÁCIO, 2010),

A Espanha estava de tal modo presente na França nos séculos XVI e XVII, que Portugal chegava a ser tomado como o seu vago duplo (PAGUEAUX, 1984), reforçando a consequente indistinção de seus patrimônios culturais. Dom Quixote é uma obra paradigmática dessa presença. Ela não só fez enorme sucesso antes mesmo de ser traduzida para o francês ${ }^{6}$, mas também difundiu nomes de diversas obras e autores ibéricos sem precisar a sua pertença. Supõe-se, aliás, que o breve elogio feito a Camões por um de seus personagens seja a primeira aparição do seu nome na França.

Em 1674, foram publicadas duas obras ${ }^{7}$ que empreendem leituras da vida e da obra de Camões, Réflexions sur la Poétique d'Aristote et sur les ouvrages des poètes anciens et modernes, de René Rapin ${ }^{8}$, e Grand Dictionnaire Historique ou le Mélange Curieux de l'Histoire Sacrée et Profane, de Louis Moréri ${ }^{9}$. A primeira critica a obscuridade dos versos do poema e censura a grandeza desmesurada da sua temática e os excessos de seus personagens (SOUSA, s/d, p. 4), enquadrando-se na herança discursiva da poética clássica então ascendente ${ }^{10}$. A segunda sublinha as características incomuns da epopeia e a aura heroica do poeta, aponta a referida obscuridade e rejeita a mistura do paganismo com a religião cristã (PAGEAUX, s/d, p. 3). Em ambas, não só constatamos os quatro principais conceitos que seriam empregados em leituras da épica camoniana até o começo do século XIX ${ }^{11}$, as noções de ancien e moderne e a dicotomia sacré e profane, mas também deparamo-nos com os dois principais pontos de divergência crítica, os excessos e a coexistência de mitologias.

Em 1685, a publicação de Jugements de savans sur les principeaux ouvrages des auteurs, de Adrien Baillet ${ }^{12}$, introduziu na França uma leitura mais favorável ao legado camoniano. Seu autor exalta entusiasmadamente o extraordinário gênio do poeta, que obtém sucesso tanto nas matérias heroicas quanto nas galantes, e elogia sua erudição, o talento particular para descrever paisagens e personagens, e a diversidade e beleza dos episódios do poema, que não desviam o leitor de seu tema principal (SOUSA, s/d, p. 6). A relevância que essa obra adquiriu após a sua reedição em 1722, revista e ampliada por
6 A tradução da primeira e da segunda parte do Quixote foram publicadas, respectivamente, em 1614 e em 1618. Entretanto, encontramos obras sobre ele em francês já na década anterior, como o Discours de Don Quixote De l'excellence des armes sur les Lettres (1609).

7 Há também a publicação na França de obras de cunho ficcional, motivadas especialmente pelos episódios de Adamastor e de Inês de Castro, que não são mencionadas neste trabalho.

8 René Rapin (1621-1687), conhecido como Père Rapin, foi jesuíta, teólogo, professor de retórica e autor de uma abundante obra em verso e em prosa, na qual se destacam Ecloge Sacra (1659) e Réflexions sur la poétique d'Aristote et sur les ouvrages des poètes anciens et modernes (1674).

9 Louis Moréri (1643-1680) foi padre, doutor em teologia e autor do Grand Dictionnaire Historique ou le Mélange Curieux de l'Histoire Sacrée et Profane (1674), uma das primeiras obras desse gênero a ter sido escrita em língua vernácula e não em latim.

10 Também em 1674 é publicada a primeira edição de L'Art Poétique, de Boileau.

11 François-René de Chateaubriand (1768-1848), por exemplo, aborda o legado camoniano em seu Génie du Christianisme (1802) dentro da tradição sacrée/chrétien e profane/ païn.

12 Adrien Baillet (1649-1706) foi teólogo, bibliotecário e autor de uma vasta obra sobre história e religião, marcadamente biográfica, na qual se destacam Vie de Descartes (1961), Jugement des savants sur les principaux ouvrages des auteurs (1685-86) e Dévotion à la Vierge et le culte qui lui est dûu (1694). 
La Monnoye ${ }^{13}$, indica um percurso de leitura até então pouco explorado na França. Isso se deve à adoção de um referencial distinto daqueles de Rapin e de Moréri que qualifica positivamente as características depreciadas por estes dois autores. Segundo Sérgio Souza (s/d, p. 5-6) e Daniel-Henri Pageaux (s/d, p. 2), Baillet remete-se diretamente à Bibliotheca Hispana Vetus (1672), de Nicolás Antonio ${ }^{14}$, e assume, assim, uma outra postura de leitura do épico, mais elogiosa e menos censória.

\section{Os Lusíadas sob a pena de Voltaire}

O Ensaio sobre o poema épico foi originalmente escrito em inglês e publicado na Inglaterra em 1727, durante o segundo exílio ${ }^{15}$ de Voltaire (1694-1778), sendo traduzido e publicado em francês em 1728. Supõe-se que se trate de um estudo preliminar para anteceder La Henriade, já que é apresentado como uma busca por uma poética contemporânea do épico. Daniel-Henri Pageaux (s/d, p. 2) comenta que inúmeros homens de letras franceses desejavam escrever um grande poema heroico, desconsiderando a Franciade, de Ronsard, e a Pucelle, de Chapelain, pois a França ainda não possuía obra semelhante. Como Voltaire parecia desejar não só o reconhecimento dos eruditos, mas também conquistar público mais amplo, ele empreende a leitura de poemas épicos de Lucano ${ }^{16}$, Virgílio $^{17} \mathrm{e}$ Homero, dos antigos, e de Tasso ${ }^{18}$, Ercilla ${ }^{19}$, Trissino ${ }^{20}$, Camões e Milton ${ }^{21}$, dos modernos, a fim de encontrar elementos que julgasse interessantes:

Temos em cada arte mais princípios do que exemplos, já que os homens possuem mais paixão para ensinar do que talento para fazer; assim há mais comentadores do que poetas, e muitos escritores, incapazes de fazer um par de versos, sufocaram-nos com artes poéticas ${ }^{22}$. (VOLTAIRE, 1728, p. $1-2$, tradução nossa)

Ele se opõe, assim, a preceitos anacrônicos e prescritivos, como os difundidos por Rapin e Boileau, e estabelece princípios e características que pudessem ou não interessar a um leitor contemporâneo. Menciona que se valeu de opiniões que encontrara registradas, supostamente de diversos países, e define, de antemão (e por unanimidade), o conteúdo do poema épico. Segundo Voltaire, o poema épico deve possuir unidade de ação, pois a inteligibilidade goza um prazer mais sensível quando ela lida com um objeto simples e proporcional ao seu olhar. Entretanto, essa unidade deve ser internamente diversificada. Ela deve ser grandiosa, para nos golpear com sua imponência; interessante, para sentirmos prazer ao sermos agitados e comovidos; e inteira, para que nada falte à satisfação do nosso espírito. Dessa maneira, quando lê a Ilíada, aponta negativamente a independência
13 Bernard de La Monnoye (1641-1728) foi advogado do parlamento de Dijon, poeta e filólogo, tendo recebido inúmeros prêmios literários. Ganhou projeção graças à publicação de Noëls bourguignons (1701), foi eleito membro de L'Académie Française em 1713 e editou diversos autores, como Adrien Baillet.

14 Nicolás Antonio (16171684) foi um erudito espanhol, diplomata e bibliófilo. Autor da Bibliotheca hispana vetus (1672) e da Bibliotheca hispana nova (1696), ele deflagra a moderna bibliografia espanhola.

15 O primeiro exílio de Voltaire ocorreu em 1716, em Tulle, após compor versos injuriosos sobre as relações amorosas do regente e da sua filha. Ele então conseguiu a autorização para se instalar no castelo do duque de Sully, que conhecera anos antes em uma sociedade libertina, La Societé du Temple, e logo obteve o perdão real. Entretanto, ele reincidiu algumas semanas depois e foi encarcerado na Bastilha, onde permaneceu por onze meses. Ao sair da prisão, começou a escrever peças de teatro, e a sua tragédia Edipe (1718) obteve enorme sucesso. Em 1726, envolveu-se em um escândalo com RohanChabot e decidiu desafiá-lo a um duelo. Contudo, acabou sendo novamente enviado à Bastilha e só foi solto com a condição de exilar-se. Instalouse então em Londres e conheceu diversos escritores, filósofos e eruditos. No ano seguinte, ele foi apresentado ao rei e o Essay on Epic Poetry foi impresso. A Henriade foi publicada em março de 1728 , dedicado à rainha da Inglaterra, e Voltaire retornou à França em outubro do mesmo ano.

16 Marco Aneu Lucano (3965), poeta romano sobrinho de Sêneca, é autor do épico inacabado Farsália, que narra a guerra civil entre Júlio César e Pompeu. 
entre os seus livros, pois deveria haver uma sequência e uma ligação necessárias entre eles. Ele também questiona a relevância dos caracteres dos seus heróis, pois, para Voltaire, Páris é vil; Menelau, vulgar; e Aquiles, excessivamente violento. Por fim, recusa-se a impor o seu juízo e deixa a cargo do leitor definir se essa obra "ainda que seja bem escrita, possa nos interessar ${ }^{23 ”}$ (VOLTAIRE, 1728, p. 30, tradução nossa).

Nessa medida, Os Lusiadas interessam Voltaire por inúmeros aspectos. $\mathrm{O}$ autor destaca a modernidade do poema, já que ele se vale de um tema inaudito para a poesia épica. Segundo ele (VOLTAIRE, 1728, p. 61-62), ninguém antes de Camões conhecera o delicioso prazer de celebrar um amigo e ações das quais fora testemunha ${ }^{24}$. Assim, o génie supérieur produziu um tipo de obra até então desconhecido, pois não se ocupara de combates sangrentos, mulheres apaixonadas e cidades destruidas. Voltaire elogia também a maneira encantadora com que o poema foi escrito e a beleza da sua elocução, que elevam a simplicidade do seu tema. Tal composição, entretanto, também ocultaria, de um modo geral, muitas das suas falhas. Por um lado, demonstra grande apreço pela alegoria do gigante Adamastor, da qual ele está convencido que "passará por bela e sublime em todos os séculos e em todas as nações ${ }^{25}$ " (VOLTAIRE, 1728, p. 64, tradução nossa). Por outro, rejeita a alegoria da Ilha dos Amores, pois a lascívia com que fora pintada agradaria apenas portugueses e italianos, a ninguém mais. Para ele,

Encontra-se em todo o curso do poema um outro tipo de maravilhoso, impossível de justificar. É uma mistura nada razoável de deuses do paganismo com os objetos da religião cristã. Vasco, durante uma tempestade, endereça seus votos a Jesus Cristo, é Vênus, entretanto, que vem ao seu socorro. (...) O maravilhoso assim tão mal arranjado desfigura todo o poema. ${ }^{26}$ (VOLTAIRE, 1728, p. 66-67, tradução nossa)

Voltaire assevera, em um parágrafo curto, ser injustificável a mistura de mitologias, ainda que tenha atribuído as qualidades de belo e sublime ao episódio de Adamastor. Ele evoca, assim, a principal falha de Os Lusíadas, independentemente dos méritos anteriormente apontados. Sucessivamente, de modo mais severo, ele desenvolve a extensão total de seu juízo:

Lembro que, após ter contado as suas aventuras ao Rei de Melinde, Vasco da Gama lhe disse: Ó, rei, julgai se Eneias e Ulisses chegaram tão longe quanto eu e escaparam de perigos semelhantes; como se esse selvagem africano tivesse algum conhecimento dos heróis de Homero e Virgílio. Acho o poema, de um modo geral, cheio de coisas excelentes e de gafes lamentáveis, colocadas, sem intervalo, umas após as outras. ${ }^{27}$ (VOLTAIRE, 1728, p. 67-68, tradução nossa)
17 Públio Virgílio Marão (70 a.C.-19 a.C.), poeta romano, é autor de épico Eneida (I a.C.), que narra a viagem de Eneias pelo mediterrâneo até a fundação de Roma.

18 Torquato Tasso (c. 1544-1595), poeta italiano contemporâneo de Ariosto, é autor do épico Jerusalém libertada (1581), que narra o combate dos cavaleiros cristãos contra os muçulmanos, durante a Primeira Cruzada, para levantar o cerco de Jerusalém.

19 Alonso de Ercilla y Zúñiga (1533-1594), escritor espanhol, é autor de La Araucana (15691589), poema épico sobre a conquista do Chile pelos espanhóis, considerado uma das obras mais importantes do Siglo de Oro.

20 Gian Giorgio Trissino (14781550), humanista italiano, é autor do épico Itália libertada dos Godos (1547-1548), que narra as campanhas na Itália do general bizantino Belissário.

21 John Milton (1608-1674), escritor e político inglês, é autor dos poemas épicos Paraíso Perdido (1667), que narra a tentação de Eva e Adão por Lúcifer e a sua decorrente expulsão do paraíso, e Paraíso Recuperado (1671), sequência do primeiro que conta a vinda de Cristo à terra para recuperar o paraíso por eles perdido.

22 Nous avons dans chaque Art plus de préceptes que d'exemples; car les hommes ont plus de passion pour enseigner que de talent pour executer; ansi il y a plus de Commentateurs que de Poëtes, \& plusieurs Ecrivains incapables de faire deux vers, nous ont accablés de Traités de Poëtique.

23 Quelque bien écrit qu'il soit, peut nous interesser.

24 Voltaire se equivoca, ao assumir que Camões participara da viagem de Vasco da Gama. 
Revela-se, assim, a dimensão de verossimilhança que norteia, direta ou indiretamente, a leitura de Voltaire. Recuperada e reformulada cerca de um século em França, ela fundamenta o seu juízo de um modo bastante particular. Diferentemente do absurdo dos caracteres dos deuses homéricos que ele aponta, as divindades de Camões não são por si só absurdas ou desinteressantes. Elas, entretanto, tornam-se profundamente incômodas ao figurar em um poema moderno, lado a lado de evocações cristãs. Voltaire é arrebatado por passagens isoladas do épico, mas, quando passa ao seu encadeamento, perde de vista a sua dimensão estética. Ele demanda de $O s$ Lusiadas uma forma de coerência no que diz respeito à escolha do pagão ou do cristão, não conseguindo conceber a sua coexistência. Dessa maneira, ao sustentar esse protocolo de leitura (CHARTIER, 2009), Voltaire acrescenta mais um elemento ao horizonte de expectativas (JAUSS, 1994) que vem definindo, supondo-o não integralmente favorável ao épico camoniano.

Os efeitos imediatos da publicação do Ensaio na França e a sua relevância no conjunto da obra de Voltaire são difíceis de precisar. $\mathrm{Na}$ mesma época, o mercado editorial francês passou a comercializar épicos modernos mencionados pelo autor ainda sem traduçãa ${ }^{28}$. Estabelecem-se, então, intrincadas relações entre públicos leitores, tradutores e editores. Publicada nessas circunstâncias, a primeira edição de La Lusiade reportase diretamente ao Ensaio sobre o poema épico, opondo-se a ele. A tensão instaurada entre as duas obras não só faz com que Voltaire a corrija, mas também condiciona uma segunda tradução do épico português ainda no século XVIII.

\section{De Os Lusíadas a La Lusiade}

La Lusiade (3 v., in-80) foi traduzida por Duperron de Castera ${ }^{29}$ (1705-1752) e publicada pela primeira vez em 1735. Ela é acompanhada de um prefácio, de uma notícia biográfica do seu autor, de extensas notas informativas e exegéticas, e de um índice. O tradutor, no prefácio, diz estar persuadido de que o parnaso francês se enriquece às custas de todas as nações que cultivam as belas letras e, assim, justifica a tradução de Os Lusíadas, "que pode passar por um dos mais belos poemas lidos após Homero e Virgílio ${ }^{30}$ " (CAMOENS, 1735, p. VI). Sequencialmente, ele faz uma breve descrição do épico:

O tema é grandioso tal como cabe a uma epopeia; é a descoberta das Índias pelos portugueses. As unidades principais de ação e dos heróis encontram-se com perfeição no poema; vê-se a sequência artisticamente ordenada, alegorias sublimes, muitos episódios bem arranjados, com
25 Passera pour belle et sublime dans tous les siècles et chez toutes les Nations.

26 On trouve dans tout le cours du Poëme une autre sorte de merveilleux, qu'il est impossible de justifier. C'est un mélange déraisonable des Dieux du Paganisme, avec les objects de la Religion Chrétienne. Verasco dans une tempête adresse ses voeux à J. C. c'est cependant Venus qui vient à son secours. (...) Un merveilleux si mal-assorti défigure tout le Poëme.

27 Je me souviens qu'après que Verasco da Gama a donné ses aventures au Roi de Melinde, il lui dit: ô Roi, juge si Enée \& Ulisse ont voyagé aussi loin que moi \& ont effuié tant de perils; comme si ce Sauvage Africain avoit quelque connoissance des Heros D'Homere \& de Virgile. Je trouve en general son Poëme plein de choses excellentes \& de bévûës pitoiables, placés sans intervalle les unes auprès des autres.

28 As traduções das obras de Trissino e de Tasso foram publicadas pela primeira vez, respectivamente, em 1559 e 1595. Os poemas de Milton e de Camões ganharam edições em francês em 1729 e 1735. A tradução de La Araucana, de Ercilla, seria publicada pela primeira vez apenas em 1824, época da efervescência camoniana em Paris.

29 Louis Adrien Duperron de Castera (1705-1752) foi monge cisterciense do convento de Santa Maria de Alcobaça, em Portugal, autor de prosa e de drama, e profícuo tradutor. Daniel-Henri Pageaux (s/d, p. 3) refere-se a ele também como diplomata. Das suas obras, encontram-se registrados Les Aventures de Léonidas et Sophonie (1722), Le Théatre des passions et de la fortune, on les amours infortunées de Rosamidor et de Théoglaphyre 
força e delicadeza (...); enfim, um estilo variado segundo a exigência dos conteúdos; às vezes doce e simples, às vezes ágil e majestoso: sempre admirável e nunca desfigurado por jogos de palavras. ${ }^{31}$ (CAMOENS, 1735, p. VII, tradução nossa, grifos nossos)

Castera afirma existir em OsLusíadas as duas principais características do poema épico elencadas por Voltaire. Segundo o tradutor, a descoberta das Índias é a unidade de ação da epopeia. Ele, porém, indica a sua diversidade interna, ao apontar a existência de uma sequência artisticamente ordenada de episódios e de alegorias. Decorrente dessa diversidade, o estilo variado é encarado como uma adequação ao conteúdo do que se narra. Ele começa, assim, a subverter o juízo de Voltaire a partir dos princípios definidos pelo próprio filósofo. A grandeza temática do épico, afirmada pelo tradutor, opõe-se à simplicidade do tema, apontada por Voltaire. A falta absoluta de jogos de palavras, sustentada pelo monge, rivaliza com a elocução que oculta falhas no poema, comentada pelo filósofo. O maravilhoso mal arranjado, que incomoda tanto Voltaire, cede a episódios bem arranjados, com força e delicadeza, que provocam a admiração de Castera. Finalmente, ainda no prefácio, ele torna explícita a sua oposição ao autor de La Henriade:

No seu Ensaio sobre o poema épico, Voltaire criticou Camões em muitos lugares; encarreguei-me de mostrá-lo, nas minhas notas, que a sua censura não se sustenta; trata-se de um embate literário no qual não emprego nem parcialidade pelo meu autor, nem fel contra aquele a cujas opiniões me oponho: estimo os seus talentos, faço justiça às belezas das suas obras, mas ele me permitirá dizer, como dizia Aristóteles em uma situação parecida: Plauto me é querido, mas a verdade me é mais. ${ }^{32}$ (CAMOENS, 1735, p. XIV-XV, tradução nossa, grifos nossos)

O protocolo de leitura de Castera inscreve-se, assim, nas numerosas notas do poema. Com a justificativa de que Camões empregara muita erudição na sua obra, o tradutor decidiu incluí-las, ao final de cada canto, para desenvolver a alegoria do épico e esclarecer algumas de suas dificuldades. Conforme o monge, elas fornecem o que é necessário para se ter uma ideia precisa do seu autor, seja sobre a história e o seu enredo, seja sobre outras coisas que fogem do comum. Nessa medida, Castera insere notas que sugerem a profunda erudição do autor (e, consequentemente, a do tradutor). No conjunto das notas, destacam-se aquelas que, abertamente, propõem-se a desacreditar a crítica de Voltaire.

$\mathrm{Na}$ nota que se segue ao Concílio dos deuses, o tradutor comenta que Camões foi censurado pela mistura dos deuses pagãos no poema. Ele,
(1731) e Le Phenix (1731). Ele traduziu do grego, do italiano, do espanhol e do português, e gostaríamos de destacar a sua tradução de Lope de Vega, Extraits de plusieurs pièces du théâtre espagnol (1738).

30 "qui peut passer pour l'un des plus beaux Poëmes, qu'on ait jamais lûs depuis Homere \& Virgile".

31 Le sujet en est grand, \& tel qu'il le faut pour l'Epopée; c'est la découverte des Indes par les Portugais. L'unité de la principale action \& celle du Héros s'y trouvent observées parfaitement; on y voit une conduite ménagée avec art, une allegorie sublime, plusieurs épisodes bienamenés avec force \& délicatesse, des peintures vives; enfin un style varié suivant l'exigence des matières; tantôt doux \& simple, tantôt rapide \& majestueux; toûjous admirable, \& jamais défiguré par ces jeux de mots (...).

32 M. de Voltaire dans son Essa sur le Poëme Epique a critiqué plusieurs endroits du Camoëns; j’ai taché de lui montrer dans mes Notes, que sa censure toimboit à faux; c'est une dispute litteraire, où [XIV] je n'apporte ni partialité pour mon Auteur, ni fiel contre celui dont je combats les opinions: j'estime ses talens, je rends justice aux beautés des ses ouvrages, mais cependant il me permettra de lui dire, ce que disoit autrefois Aristote en pareille conjoncture: Amicus Plato, sed magis amica veritas. 
entretanto, afirma que as censuras vieram de pessoas que não compreendiam o épico, ou que não consideravam os privilégios da poesia heroica:

Os devotos se escandalizaram ao encontrar os nomes profanos de Júpiter, de Mercúrio e de Vênus em ações onde o verdadeiro Deus demonstrou seu poder e bondade em relação à felicidade da Europa e à conversão dos orientais: outros, menos escrupulosos, mas também pouco esclarecidos, julgaram que o maravilhoso retirado das fontes da fábula não é capaz nem de nos provocar admiração, nem de nos interessar, já que conhecemos as suas falhas. Esse é um dos principais pontos em que Voltaire fundamenta a sua crítica (...). ${ }^{33}$ (CAMOENS, 1735, p. 58-59, tradução nossa, grifos nossos)

A argumentação de Castera visa a provar que o emprego das divindades pagãs no poema não é criminoso e que nada compromete o interesse e a admiração provocados por Os Lusiadas. Ele sustenta que a intervenção de Júpiter e das demais divindades na epopeia se justifica, já que há uma equivalência teológica entre eles e o Deus cristão. Conforme provas indubitáveis de que dispõe, ele afirma que a mitologia pagã reconheceu apenas a um deus como todo poderoso: Zeus para os gregos; Serápis para os egípcios; Oromasis para os magos; e Júpiter para os romanos. Posteriormente, inventou-se nomes que exprimissem, de modo mais particular, seus atributos. Dessa maneira, esse ser soberano era Marte, ao decidir a sorte dos guerreiros; Netuno, ao apaziguar ou elevar as ondas; e Ceres, ao tornar fecunda a terra. Consequentemente, de um ponto de vista eminentemente religioso, Deus e Júpiter (e seus atributos) estabelecem a mesma relação com o mundo. $\mathrm{O}$ monge, sequencialmente, evoca alguns procedimentos poéticos comumente encontrados em poemas heroicos. Ele parte da declaração de Tasso de que a alegoria é a alma da epopeia e diz ser necessário invadir o espirito do autor para poder penetrar o seu sentido misterioso e mesmo descobrir belezas inesperadas ${ }^{34}$. Ele comenta que os nomes de Jesus Cristo e de São Miguel Arcanjo não foram utilizados com frequência para se compor epopeias e que as virtudes, os vícios e as paixões foram personificados e se tornaram divindades de modo recorrente em poemas heroicos. Assim, ele reconhece que a decisão de não recorrer a nomes cristãos e de personificar elementos abstratos são boas e assevera que elas são legítimas,

(...) pois se permitimos a Boileau ${ }^{35}$ incluir no seu Lutrin a chicana e a volupté, que se tornam novas divindades, não entendo porque proscrevemos o emprego dos nomes de Febo e de Tétis em Os Lusíadas, que o Parnaso já conhece.
33 Les dévots ont été scandalisés de rencontrer les noms profanes de Jupiter, de Mercure \& de Venus, \&c. dans des actions où le vrai Dieu a signalé sa puissance \& sa bonté pour le bonheur de l'Europe, \& pour la conversion des Orientaux: d'autres moins scrupuleux, mais aussi peu éclaires, ont jugé que le merveilleux puisé dans les sources de la Fable, n'est propre ni à nous frapper d'admiration, ni à nous interesser, maintenant que nous en connoissons le faux. C'est-là l'un des principaux points sur lesquels M. de Voltaire fonde la critique (...).

34 Segundo Castera, foi assim que "os estudiosos sempre encontraram em Homero o que admirar, enquanto os ignorantes, que se detinham apenas na superfície das palavras, olharam-no com desprezo" (CAMOENS, 1735, p. 63, tradução nossa, grifos nossos).

35 Nicolas Boileau (1636-1711) foi um poeta e erudito francês. Ele publicou as suas primeiras sátiras em 1666, obtendo grande sucesso, e foi eleito membro de L'Académie Française, por recomendação de Louis XIV, em 1684. Ele é um dos responsáveis, junto a Racine, pela disseminação de princípios da poética clássica na França, pois ele não só defendeu, sucessivas vezes, a posição dos antigos na Querela dos antigos e dos modernos, mas também empreendeu uma tradução de Do Sublime [Traité du sublime] (1674), de Longino, e escreveu uma Arte poética (1674). Le Lutrin (1672), mencionado por Castera, é uma tentativa de composição de uma epopeia a partir de temas mundanos, que culmina em uma narrativa profundamente satírica e paródica. No século XVIII, Boileau é um dos autores mais respeitados do cânone francês, e a equiparação dele e de Camões, feita por Castera, é bastante provocativa. 
A alegoria é a mesma para ambos os lados, ele deve então servir de passaporte ao poeta do Tejo da mesma forma como serviu ao do Sena. ${ }^{36}$ (CAMOENS, 1735, p. 63, tradução nossa, grifos nossos)

Nas notas que se seguem à aparição de cada Deus, Castera invade o espírito de Camões e desvela a alegoria de Os Lusíadas. Segundo o tradutor, Júpiter representa Deus Pai, uma vez que o poeta lhe concedeu os mais belos traços, os mesmos empregados pela Santa Escritura para descrever a imagem divina, e uma voz imponente, que inspira terror e respeito, atribuída ao criador também por Jó. Baco representa o Diabo, já que se opõe à viagem dos portugueses por prever que eles, convertendo os orientais, acabariam com o culto dedicado a ele. Ele acrescenta que o demônio obscurece a luminosidade da alma com a tentação dos prazeres, assim como o deus pagão faz com a doçura do vinho, além de ambos possuírem chifres. De maneira oposta, Vênus representa a Religião Cristã $^{37}$, pois protege os viajantes portugueses ao se dar conta das vantagens que a Igreja pode tirar dessa conversão. Marte ${ }^{38}$, sequencialmente, representa Jesus Cristo, pois o filho de Deus combateu pela humanidade, e podemos chamá-lo, sem culpa, de Deus da Guerra ${ }^{39}$. Mercúrio, enfim, mensageiro de Júpiter, representa os anjos, mensageiros de Deus.

$\mathrm{Na}$ nota que se segue à última passagem do Canto II, quando o rei de Melinde pede a Gama que fale sobre Portugal, Castera procura justificar a erudição atribuída a ele, veementemente condenada por Voltaire. Ele se encarrega de inventariar, desde Alexandre, as inúmeras circunstâncias em que os mouros puderam ter tido acesso ao patrimônio dos antigos, de modo indagador e assertivo:

Podemos ignorar que os indianos tenham, um dia, se relacionado com os gregos? Os filósofos gregos não viajavam por todo Oriente para consultar os magos e os brâmanes? (...) Não é um fato verídico que Alexandre esteve nas Índias, que as conquistou e que lá permaneceu por algum tempo? Sabemos que esse príncipe cultivava as belas letras; ele nos ofereceu o mais nobre testemunho quando, um dia, tendo encontrado o cofre de Dario entre os despojos dos persas, disse que havia nada mais precioso para colocar dentro dele do que as obras de Homero. (...) Como todo o universo segue o exemplo dos reis e os seus sentimentos têm a força das leis, podemos crer que a corte de Alexandre imitava o seu gosto pelas ciências (...). Nesse caso, não faríamos mal em inferir que, durante a sua estadia nas Indias, os povos desses climas aprenderam a mitologia, a história e muitas coisas semelhantes; ou, se não foi durante a sua estadia, ao menos não temos dúvidas de que isso não pôde deixar de ser feito
36 (...) cette conduite est bonne; mais en même temps je dis que'elle autorise celle du Camoëns; car si l'on permet à Boileau d'introduire dans son Lutrin la chicane \& la volupté, qui font des Déesses nouvelles; je ne comprends pas pourquoi l'on défendroit au Camoëns d'employer dans la Lusiade les noms de Pohoebus \& de Thétis, que le Parnasse connoît déjà. L'alégorie est égale des deux côtés, elle doit donc servir de passeport au Poëte du Tage, aussi-bien qu’à celui de la Seine.

37 Contra a polêmica que essa associação poderia causar, Castera (CAMOENS, 1735, p. 67) comenta que Platão, em $O$ banquete, distingue duas Vênus: uma terrestre e lasciva, outra celeste e pura, sendo da última que o poeta fala.

38 Quanto ao amor de Marte por Vênus mencionado pelo poeta, é preciso entendê-lo, segundo Castera, como o amor de Jesus pela Igreja.

39 Especialmente se levarmos em consideração a descrição oferecida por São João no segundo capítulo do Apocalipse. 
depois da sua partida $(\ldots)^{40}$. (CAMOENS, 1735 , p. $172-$ 173 , tradução nossa)

Castera comenta que o grego foi largamente disseminado na Ásia, especialmente por meio das cidades fundadas por Alexandre, pois lá se encontram muitos lugares, plantas e animais com nomes nessa língua ${ }^{41}$. Ele acrescenta que os indianos também mantiveram relações com os romanos, haja vista os testemunhos de Macróbio, de Plínio e de outros autores por ele referidos, e puderam, por meio deles, ter acesso à mitologia e aos poetas. Ele também afirma que os mouros, tendo invadido a Espanha, "se dedicaram ao estudo (...), traduziram e comentaram na sua língua as melhores obras dos gregos e dos latinos" ${ }^{\text {"2 }}$ (CAMOENS, 1735,p. 175, tradução nossa) e, quando foram finalmente expulsos, levaram para a África e para a Ásia as ciências que aprenderam na Europa. Enfim, com tantos esclarecimentos, Castera duvida que ainda se acredite que Camões tenha ferido a verossimilhança do poema ao representar um rei mouro que conhece a fábula antiga. Ao cabo, assevera, resolutamente, que, como testemunha a similaridade do gigante de Simbá com Polifermo, "os censores devem se lembrar que os contos das Mil e Uma Noites, com recorrência, nada fazem além de imitar Virgílio, Homero e Ovídio"43 (CAMOENS, 1735, p. 176, tradução nossa).

\section{Leituras mais afamadas do que ditosas}

O Ensaio sobre o poema épico e La Lusiade foram publicados em uma fase de passagem da dependência reforçada do Estado para uma crescente profissionalização do escritor no que se refere ao processo de autonomização do campo literário francês (SAPIRO, 2004, p. 94). Dessa maneira, ambos encenam um debate acerca do épico camoniano que funciona de maneira metonímica em relação a outras disputas, já que ele não integra uma instância de consagração específica. Dito de outra forma, ambos veiculam juízos críticos cuja função não se limita a avaliar literariamente Os Lusíadas, pois também se imbricam em questões extraliterárias. A proximidade entre as datas de publicação de La Henridade na Inglaterra e a permissão de retorno à França, bem como a da ordem de prisão decorrente das Cartas Filosóficas e a da impressão de La Lusiade indicam movimentos de valorização e de desvalorização de Voltaire como escritor e intelectual, que culminam com a sua institucionalização, ${ }^{44}$ ao ser eleito membro de L'Académie Française em 1746. Isso faz com que os juízos do filósofo se fortaleçam, e a posição de Castera se encontre fragilizada. De fato, a segunda tradução de Os Lusíadas (1776), realizada por Vaquette d'Hermilly ${ }^{45}$ e La Harpe ${ }^{46}$, foi publicada logo após a reedição da primeira tradução $(1768)^{47}$ e se coloca abertamente contra a de Duperra e a favor do filósofo. Tendo em vista o debate e as suas implicações, pode-se sustentar que a recepção do épico português foi
40 Peut-on ignorer que les Indiens ayent été jadis en liaison avec les grecs? Les Philosophes de la Grece ne voyageoientils pas dans tout l'Orient pour y consulter les Mages \& les Brachmanes? (...) n'estce pas encore un fait certain qu'Alexandre a été dans les Indes, qu'il les a conquises, \& qu'il y a sejourné? On sçait que ce Prince chérissoit les belles lettres; il le témoigna hautement, lorsqu'un jour ayant trouvé l'Ecrin de Darius parmi les dépuilles des Persans, il dit qu'il n'avoit rien de plus précieux à renfermer dans ce petit coffre, que les Oeuvres d'Homere. (...) Puisque tout l'univers suit l'exemple des Rois, et que leurs sentimens ont la force des Loix, nous puvons croire que les courtisans d'Alexandre imitoient son goût pour les sciences (...). En ce cas, nous n'aurons pas tort d'inferer que pendant son séjour dans les Indes, les Peuples des ces climats apprirent la Mythologie, l'Histoire \& plusieurs autres choses semblables; ou si ce ne fut pas durant qu'il demeura chez eux, au moins est-il indubitable que cela n'a pû manquer d'arriver après son départ (...).

41 Castera cita a cidade de Agra. Conforme o monge, agra, em grego, significa caça: os mongóis construíram a cidade em um local onde Gengis Khan, seu primeiro imperador, realizou um dia uma grande caçada.

42 “(...) il s'y appliquerent à l'étude (...), ils traduirent, ils commenterent dans leur langue les meilleurs ouvrages des Grecs \& des Latins (...)"

43 Les Censeus devroient se ressouvenir que les Contes Arabes du Dervis Moclès, qui nous sont connus sous le titre de Mille \& une nuits, ne font souvent qu'imiter Virgile, Homère \& Ovide, témoin l'Histoire du Géant de Sindbad, qui ressemble parfaitement à celle de Polipheme. 
fomentada não só pelo interesse que o poema suscitava, mas também pelas polêmicas em que se inscrevia.

Os Lusíadas não saiu imune dessas controvérsias. Elas acabaram interferindo e condicionando as suas leitura e recepção na França, já que encontraram contrapartida gráfica na materialidade das traduções. Assim, um leitor, qualquer que fosse, era invariavelmente exposto à querela, pois ela se apresenta no prefácio, introdução e notas tanto da primeira quanto da segunda tradução. A figura de Camões e o seu legado, consequentemente, não são inseridos ${ }^{48}$ no campo literário francês sem ônus, já que sobre eles incidem juízos que mais dizem respeito à legitimação ou à difamação de quem os proferiu do que a uma avaliação do valor literário do poema. Tal incidência adquire tamanha relevância, que leituras posteriores a mencionam mesmo que ela não seja diretamente relevante nesses novos horizontes de expectativa. De fato, no começo do século XIX, alguns admiradores de Camões queriam a tal ponto produzir um juízo genuinamente literário do épico, que dialogaram, invariavelmente, com Voltaire e Castera. Tais tentativas acabaram deflagrando um processo de recepção que se constitui na autonomização do campo literário francês e atravessa o século XIX, acumulando outras leituras, traduções e polêmicas.

\section{REFERENNCIAS}

AGUIAR E SILVA, Victor Manuel de. Notas sobre o cânone da lírica camoniana (II). In: Revista de História Literária de Portugal. Coimbra: Coimbra Editora, 1975, p. 87-122.v. IV

ANASTÁCIO, Vanda. A criação de um poeta nacional: breve panorâmica das edições da lírica camoniana entre 1595 e 1870. In: Floema, ano VI, n. 7, p. 61-74, jul./dez. 2010. Disponível em: <http://periodicos.uesb.br/index. php/floema/article/viewFile/466/508>. Acesso em 30 de outubro de 2012.

ANASTÁCIO, Vanda. Leituras potencialmente perigosas: reflexões sobre as traduções castelhanas de Os Lusíadas no tempo da União Ibérica. In: Revista Camoniana, 3a série, n. 15. São Paulo: EDUSC, 2004. p. 159-178.

AZEVEDO FILHO, Leodegário de. Sobre o cânone lírico de Camões. In: Revista Colóquio/Letras, n. 99, Set. 1987. p. 10-19.

CAMOENS. La Lusiade du Camoens: poëme héroïque sur la découverte
44 Gisèlle Sapiro (2004) comenta que a Academia Francesa foi oficializada quando o rei delegou a ela o poder de legislar em matéria de linguagem, provocando, por um lado, a liberação parcial da atividade literária do clientelismo e, por outro, a sua sujeição ao poder real.

45 Nicolas-Gabriel Vaquette d'Hermilly (1705-1778) foi intelectual, militar e proeminente tradutor francês. Ele viveu um longo período em Madri, onde frequentou os meios intelectuais ligados à Real Academia Española, e retornou à França em 1742, empregando-se primeiramente como inspetor militar e, posteriormente, como censor. Ele traduziu inúmeras obras espanholas e portuguesas para a língua francesa, entre as quais se destacam a Histoire générale d'Espagne (1742-1751, $10 \mathrm{v}$ ), originalmente de Juan de Ferraras, Discurso sobre las tragedias españolas (1754), de Agustín de Montiano y Luyando, e de uma seleção de obras de Francisco de Quevedo (1776).

46 Jean-François de La Harpe (1739-1803) foi um escritor e crítico francês, de origem suíça. Em 1759, ele passou a contar com a proteção de Voltaire ao publicar uma obra anticlerical, Hérö̈des, e, em 1776, foi eleito membro de L'Académie Française graças ao incondicional apoio do filósofo. La Harpe recebeu o prêmio de eloquência da academia pelo seu Éloge a Voltaire em 1779 , ano posterior à morte do filósofo, e renunciou $\operatorname{logo}$ depois à sua poltrona, passando a lecionar literatura. Tendo apoiado calorosamente a revolução francesa, foi preso em 1794 e, ao sair da prisão, passou a demonstrar publicamente posicionamento conservador, frequentando igrejas e desferindo ataques aos iluministas.

47 A primeira edição de $L a$ Lusiade foi impressa por quatro casas editoriais (Huart, David, Cloussier e Briasson); a sua reedição, apenas por uma delas (Briasson). 
des Indes Orientales. Traduite du portugais par M. Duperron de Castera. Paris: HUART/DAVID/BRIASSON/CLOUSIER, 1735, t. 1 Disponível em: <http://archive.org/stream/lalusiadeducamoe01camuoft\#page/n13/ mode/2up >. Acesso em 14 de abril de 2012.

CARVALHAL, Tânia Franco. Tradução e recepção na prática comparatista. In: O próprio e o alheio. São Leopoldo: Unisinos, 2003, p. 217-259.

CHARTIER, Roger. Do livro à leitura. In: Práticas da leitura. Tradução de Cristiane Nascimento. São Paulo: Estação Liberdade, 2009. p. 77-105.

HUE, Sheila Moura. A impressão da lírica dos contemporâneos de Camões. In: Floema, ano V, n. 5, p. 65-98, out 2009. Disponível em: <http:// periodicos.uesb.br/index.php/floema/article/viewFile/129/332>. Acesso em 30 de outubro de 2012.

JAUSS, Hans Robert. Aesthetic experience and literary hermeneutics. Translation from the German by Michael Shaw. Introduction by Wlad Godzich. Minneapolis: University of Minnesota Press, 1982.

JAUSS, Hans Robert. A história da literatura como provocação à teoria literária. Traduzido do alemão por Sérgio Tellaroli. São Paulo: Editora Ática, 1994.

PAGEAUX, Daniel-Henri. Imagens de Portugal na cultura francesa. Lisboa: Instituto de Cultura e Língua Portuguesa, 1984.

PAGEAUX, Daniel-Henri. Visages d'une oeuvre: Les Lusiades de Camoens en France. (mimeo, s/d)

PIRES, Maria Lucília Gonçalves. A crítica camoniana no século XVII. Amadora: Instituto de Cultura e Língua Portuguesa, 1982.

SAPIRO, Gisèle. Elementos para uma história do processo de autonomização. Tempo Social, São Paulo, v. 16, n. 1, jun./2004. Disponível em: <http://www.fflch.usp.br/sociologia/temposocial/site/images/stories/ edicoes/v161/v16n1a05.pdf>. Acesso em 30 de outubro de 2012.

SOUSA, Sérgio Paulo Guimarães de. Sobre a recep̧̧ão de Os Lusíadas em França até ao século XVIII. Disponível em: <http://www.letras.ufmg.br/ cesp/textos/(1998)05-Sobre.pdf>. Acesso em 25 de janeiro de 2012.

VOLTAIRE. Essay sur la poësie epique. Traduit de l'anglois de M. de Voltaire. Paris: Chaubert, 1728.
48 Consideramos que uma obra apenas se insere em um campo literário por meio da sua tradução (CARVALHAL, 2003, p. 230). 